\title{
PERKIRAAN KONSUMSI ENERGI LISTRIK DI ACEH PADA TAHUN 2028 MENGGUNAKAN METODE ADAPTIVE NEURO FUZZY INFERENCE SYSTEM
}

\author{
Yoga Tri Nugraha ${ }^{1}$, M. Fitra Zambak ${ }^{2}$, Arnawan Hasibuan ${ }^{3}$ \\ 1,2,3 Program Pascasarjana, Magister Teknik Elektro, Universitas Muhammadiyah Sumatera Utara \\ Jl. Denai No. 217, Medan, 20371, Indonesia \\ 1yoga_nugraha14@yahoo.com, ${ }^{2}$ mhdfitra@gmail.com, ${ }^{3}$ nawan_hsb@yahoo.co.id
}

\begin{abstract}
Abstrak-Konsumsi energi listrik di Aceh semakin meningkat dari tahun ke tahun. Faktor yang menyebabkan meningkatnya konsumsi energi listrik di Aceh adalah Pertumbuhan Penduduk, dan Ekonomi. Untuk memenuhi akan kebutuhan konsumsi energi listrik yang semakin meningkat dari tahun ke tahun, maka dilakukan perkirakan konsumsi energi listrik jangka panjang selama 10 tahun yaitu pada tahun 2028 di Aceh. Untuk memperkirakan konsumsi energi listrik ini memerlukan sebuah metode yang dapat mendekati hasil aslinya. Metode tersebut yaitu Metode Adaptive Neuro Fuzzy Inference System. Hasil yang didapat dalam memperkirakan konsumsi energi listrik pada tahun 2028 di Aceh dengan menggunakan metode ini adalah sebesar 5578,02 GWh atau dengan kenaikan 2,07\% setiap tahunnya sampai tahun 2028 .
\end{abstract}

Kata kunci-Perkiraan Konsumsi Energi Listrik, Adaptive Neuro Fuzzy Inference System, Penduduk, Ekonomi (PDRB HK 2010).

Abstract-Electricity consumption in Aceh is increasing from year to year. Factors causing increased electricity consumption in Aceh are Population Growth, and Economy. To meet the need for electricity consumption which is increasing from year to year, then it is forecast that the long-term consumption of electrical energy for 10 years is in 2028 in Aceh. To estimate the consumption of electrical energy requires a method that can approach the original results. The method is the Adaptive Neuro Fuzzy Inference System Method. The results obtained in estimating electricity consumption in 2028 in Aceh using this method amounted to 5578,02 GWh or with an increase of $2,07 \%$ every year until 2028 .

Keywords-Estimated Electric Energy Consumption, Adaptive Neuro Fuzzy Inference System, Population, Economy (PDRB HK 2010).

\section{PENDAHULUAN}

Seiring dengan meningkatnya pertumbuhan jumlah penduduk, dan pertumbuhan ekonomi, maka kebutuhan energi listrik akan terus meningkat dari tahun ke tahun. Hal ini sejalan dengan aktifitas kehidupan masyarakat yang bergantung pada ketersediaan pasokan energi listrik. Oleh karena itu perlu adanya penyediaan pasokan energi listrik dalam jumlah yang cukup serta handal dengan harga yang terjangkau untuk kebutuhan masyarakat

Pada saat ini energi listrik telah menjadi kebutuhan primer bagi kehidupan manusia modern untuk melaksanakan kegiatan sosial dan ekonomi untuk mencapai taraf hidup yang lebih baik. Sehingga besarnya tingkat pemakaian energi listrik dapat juga dianggap sebagai tolak ukur tingkat pendapatan dan kemakmuran bagi suatu negara atau daerah. Selanjutnya dilihat dari peranan listrik dalam perekonomian, industri listrik termasuk industri hulu, sehingga pengembangannya dapat merangsang sektorsektor lain yang memanfaatkan energi listrik sebagai masukannya[1].
Populasi penduduk memiliki hubungan positif terhadap konsumsi listrik.Dampak populasi tersebut terhadap konsumsi listriksecara statistik signifikan.Hal ini mengindikasikan bahwa, dengan bertambahnya penduduk akan meningkatkan konsumsi energi listrik[2]. Pertumbuhan penduduk Aceh dari tahun ke tahun mengalami peningkatan. Dengan pertumbuhan penduduk ini dapat mempengaruhi dari konsumsi energi listrik yang ada di Aceh.

Pertumbuhan ekonomi memiliki hubungan positif terhadap konsumsi listrik yang secara statistik signifikan. Hal ini mengindikasikan bahwa dengan meningkatnya pertumbuhan ekonomi, maka akan mengingkatkan konsumsi energi listrik[2]. Pertumbuhan ekonomi di Aceh dari tahun ke tahun mengalami peningkatan. Dengan pertumbuhan ekonomi ini dapat mempengaruhi dari konsumsi energi listrik yang ada di Aceh. Pertumbuhan ekonomi ini dapat dilihat dari Produk Domestik Regional Bruto HK 2010 Provinsi Aceh.

Untuk memenuhi kebutuhan tersebut, maka kita harus mengetahui kebutuhan energi listrik dalam 
beberapa tahun kedepan. Dengan cara membuat perkiraan kebutuhan (demand forecast) energi listrik. Perkiraan kebutuhan energi listrik merupakan langkah awal dalam menyusun perencanaan pertumbuhan sistem kelistrikan. Dalam membuat perkiraan kebutuhan energi listrik, sebaiknya menggunakan metode yang menghasilkan output lebih mendekati hasil pada realisasinya, serta dapat dipertanggungjawabkan. Hasil perkiraan yang terlalu rendah (under estimate) mengakibatkan akan terjadinya pemadaman bergilir serta pasokan energi listrik tidak mencukupi untuk kebutuhan kehidupan masyarakat. Dan jika hasil perkiraan yang terlalu tinggi (over estimate) mengakibatkan investasi yang terlalu besar dan dapat merugikan perusahaan tersebut[3].

Oleh karena itu, perkiraan kebutuhan energi listrik ini memiliki peranan yang sangat penting dan mendasar dalam menyusun rencana pengembangan sistem ketenagalistrikan disuatu daerah atau wilayah. Untuk menunjang hal tersebut perlu memilih metode yang sesuai dan mudah dalam pelaksanaan perhitungannya.

Berdasarkan uraian di atas, dalam penelitian ini akan dilakukan penelitian tentang "Perkiraan Konsumsi Energi Listrik Di Aceh Pada Tahun 2028 Menggunakan Metode Adaptive Neuro Fuzzy Inference System".

Penelitian ini dilakukan dengan tujuan untuk menganalisa faktor-faktor yang mempengaruhi konsumsi energi listrik, dan menganalisa perkiraan konsumsi energi listrik di Aceh pada tahun 2028.

\section{TINJAUAN PUSTAKA}

\section{A. Konsep Dasar Perkiraan (Forecasting)}

Pada beberapa tulisan mengenai forecasting, terkadang diartikan sebagai peramalan atau prakiraan atau perkiraan, namun sebenarnya mempunyai pengertian yang sama yaitu memprediksi suatu nilai dimasa yang akan datang. Memprediksi masa depan itu pada dasarnya sangat sulit (Nils Bohr). Membuat prakiraan (forecasting) kebutuhan tenaga listrik merupakan langkah awal dari suatu rangkaian kegiatan dalam membuat rencana pengembangan sistem ketenagalistrikan yang meliputi pembangkit, penyaluran dan distribusi. Kebutuhan tenaga listrik dipengaruhi oleh beberapa faktor antara lain pertumbuhan jumlah penduduk, pertumbuhan ekonomi, energi substitusi, kemampuan disisi pasokan, dan di beberapa negara dipengaruhi juga oleh harga jual listrik kepada pelanggan, faktor musim, perubahan struktur ekonomi, dan sebagainya[3]. Bila dilihat dari horizon waktu, maka perkiraan kebutuhan listrik dapat dikelompokkan menjadi 3 yaitu:

a. Jangka pendek sampai dengan 2 tahun, yaitu mulai harian, mingguan, bulanan, hingga tahunan, biasa digunakan untuk perencanaan operasional. Sedangkan periode 1 sampai dengan 2 tahunan biasa digunakan untuk perencanaan anggaran (RKAP).

b. Jangka menengah 3 sampai 5 tahun, digunakan untuk perencanaan stategi korporat, pembangkit skala kecil dan untuk masterplan sistem distribusi.

c. Jangka panjang 10 tahun, digunakan untuk perencanaan pengembangan sistem pembangkitan, transmisi dan gardu induk, sebagaimana produk RUPTL.Jangka panjang 20 sampai 50 tahun, digunakan untuk menyusun master plan pengembangan sistem.

\section{B. Adaptive Neuro Fuzzy Inference System (ANFIS)}

Sistem Neuro Fuzzy berstruktur ANFIS (Adaptive Neuro Fuzzy Inference System atau biasa disebut juga Adaptive Network based Fuzzy Inference System) termasuk dalam kelas jaringan neural namun berdasarkan fungsinya sama dengan Fuzzy Inference System. Pada sistem Neuro Fuzzy, proses belajar pada neural network dengan sejumlah pasangan data yang berguna untuk memperbaharui parameter-parameter Fuzzy Inference System[4].

Sebagai contoh, untuk model fuzzy Sugeno OrdeSatu, aturan yang umum dengan dua aturan fuzzy IF THEN sebagai berikut:

RULE 1 : IF $\mathrm{x}$ is $\mathrm{A}_{1}$ AND $\mathrm{y}$ is $\mathrm{B}_{1}$, THEN $\mathrm{f}_{1}=\mathrm{p}_{1} \mathrm{x}+$ $\mathrm{q}_{1} \mathrm{y}+\mathrm{r}_{1}$

RULE 2 : IF $\mathrm{x}$ is $\mathrm{A}_{2}$ AND $\mathrm{y}$ is $\mathrm{B}_{2}$, THEN $\mathrm{f}_{2}=\mathrm{p}_{2} \mathrm{x}+$ $\mathrm{q}_{2} \mathrm{y}+\mathrm{r}_{2}$

dengan $\mathrm{x}$ dan y adalah masukan tegas pada node ke $\mathrm{i}$, $A_{i}$ dan $B_{i}$ adalah label linguistik (rendah, sedang, tinggi, dan lain-lain) yang dinyatakan dengan fungsi keanggotaan yang sesuai, sedangkan $\mathrm{p}_{\mathrm{i}}, \mathrm{q}_{\mathrm{i}}$, dan $\mathrm{r}_{\mathrm{i}}$ adalah parameter consequent ( $\mathrm{i}=1$ atau 2$)$.

Data yang digunakan untuk proses pembelajaran (training) terdiri dari data masukan, parameter ANFIS, dan data test yang berada pada periode training ANFIS yang kemudian dilakukan proses pembelajaran terhadap data-data tersebut sehingga nantinya diperoleh output berupa hasil prediksi[5].

Training dengan ANFIS menggunakan algoritma belajar hybrid, dimana dilakukan penggabungan metode Least-Squares Estimator (LSE) untuk menghitung nilai consequent pada alur maju dan menggunakan Error Backpropagation (EBP) dan gradient descent pada alur mundur untuk menghitung error yang terjadi pada tiap layer.

ANFIS terdiri dari lima layer. Pada layer pertama terdiri dari proses fuzzifikasi dimana data masukan dan target dipetakan dalam derajat keanggotaannya. Pada layer kedua dan ketiga dilakukan proses inferensi yang digunakan untuk menentukan rule fuzzy menggunakan inferensi Sugeno dimana hasilnya akan diproses pada perhitungan selanjutnya. Pada layer 4 dilakukan proses pencarian nilai consequent dengan menggunakan LSE. Pada layer 5 dilakukan proses summary dari dua keluaran pada layer 4. Pada ANFIS, Fuzzy Inference System (FIS) terletak pada layer 1, 2, 3 dan 4 dimana FIS adalah sebagai penentu hidden node yang terdapat pada sistem neural network[5]. 
Setelah perhitungan alur maju dilakukan perhitungan alur mundur untuk menghitung nilai error tiap layer dan mengubah nilai parameter masukan menggunakan gradient descent. Proses perhitungan di atas akan berulang terus menerus sampai nilai error memenuhi nilai error maksimum yang telah ditentukan[6]. Alur proses dari sebuah sistem ANFIS yang terdiri dari lima layer digambarkan pada Gambar 1.

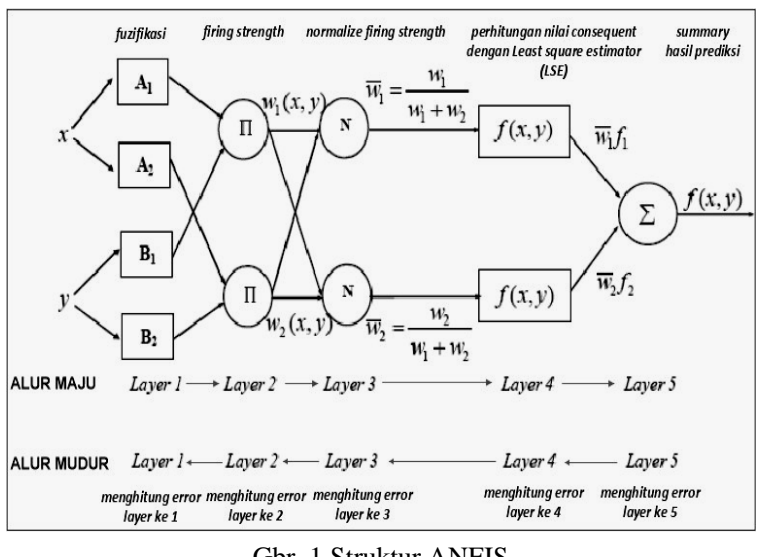

Setelah mendapatkan hasil akhir, maka akan mencari nilai kesalahan pada hasil akhir tersebut dengan menggunakan rumus :

MAPE $=\frac{\sum \frac{a-b}{a}}{n} \times 100 \%$

Dimana :

$\mathrm{a}=$ Data aktual

$\mathrm{b}=$ Hasil data prediksi;

$\mathrm{c}=$ Jumlah tahun perkiraan.

\section{METODE PENELITIAN}

Dalam penelitian tentang perkiraan konsumsi energi listrik ini menggunakan metode Adaptive Neuro Fuzzy Inference System. Tempat pada penelitian ini adalah PT. PLN (Persero) dan Badan Pusat Statistik (BPS) Provinsi Aceh. Populasi dalam penelitian ini adalah Konsumsi Energi Listrik Di Sumatera Utara. Sampel dalam penelitian ini adalah data pertumbuhan penduduk AcehTahun 2013-2017, data pertumbuhan ekonomi (PDRB)AcehTahun 2013-2017, dan data konsumsi energi listrik Provinsi Aceh Tahun 20132017.

Teknik pengumpulan data dalam penelitian ini dilakukan dengan cara studi literatur digunakan untuk mencari data penelitian mengenai perkiraan konsumsi energi listrik yang meliputi studi definisi perkiraan konsumsi energi listrik, pengumpulan data yaitu dengan melakukan pengumpulan data mengenai perkiraan konsumsi energi listrik, pertumbuhan jumlah penduduk, dan pertumbuhan ekonomi (PDRB).Kemudian pengolahan data dan analisa yaitu dengan melakukan perancangan data yang telah dikumpulkan dan menganalisis data tersebut serta melakukan pengujian dengan data tersebut. Adapun prosedur penelitian sebagai berikut :

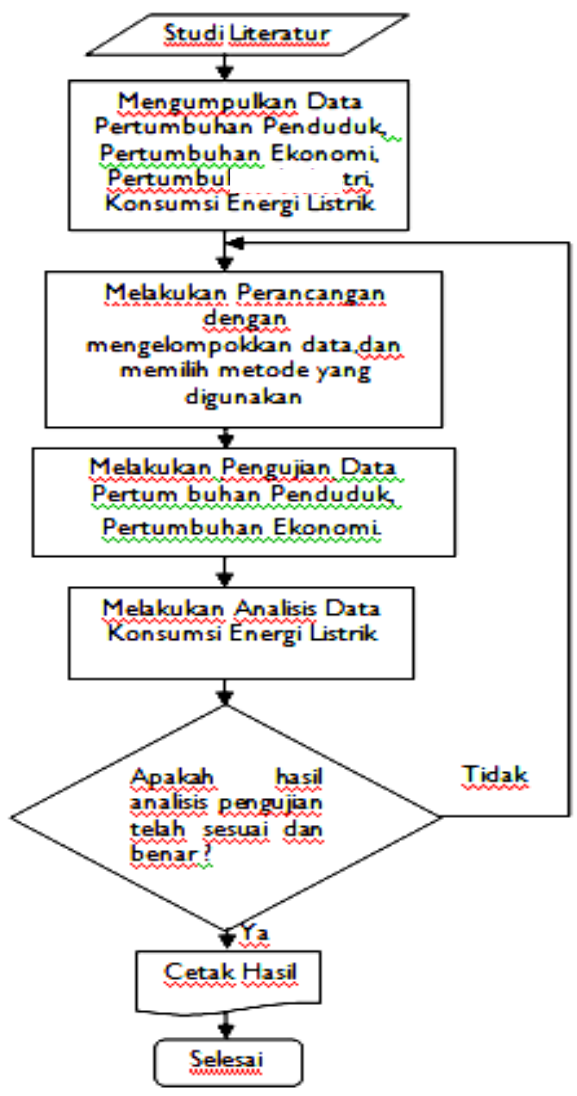

Gbr. 2 Prosedur Penelitian

\section{HASIL DAN PEMBAHASAN}

\section{A. Faktor-Faktor Yang Mempengaruhi Konsumsi Energi Listrik}

Adapun faktor-faktor yang mempengaruhi tingkat pemakaian konsumsi energi listrik adalah :

1. Pertumbuhan Jumlah Penduduk

Dalam menentukan perkiraan pertumbuhan penduduk di Aceh, maka diperlukan data realisasi pertumbuhan penduduk dari tahun 2013 sampai 2017 dan dengan menggunakan software Aplikasi Simple E. Adapun hasil perhitungan perkiraan pertumbuhan jumlah penduduk pada tahun 2032 yang didapat menggunakan Aplikasi Simple E adalah dengan ratarata pertumbuhan sebesar $1,8 \%$.

\section{Pertumbuhan Ekonomi}

Dalam menentukan perkiraan pertumbuhan ekonomi di Aceh, maka diperlukan data realisasi pertumbuhan ekonomi dari tahun 2013 sampai 2017 dan dengan menggunakan software Aplikasi Simple E. Adapun hasil perhitungan perkiraan pertumbuhan ekonomi pada tahun 2032 yang didapat menggunakan Aplikasi Simple E adalah dengan rata-rata pertumbuhan sebesar $2,08 \%$. 


\section{B. Perkiraan Konsumsi Energi Listrik Di Aceh}

Ketika memasukkan pengujian data ke dalam program ANFIS, maka akan membentuk blok diagram ANFIS. Dapat dilihat pada Gambar 3.

Page | 107

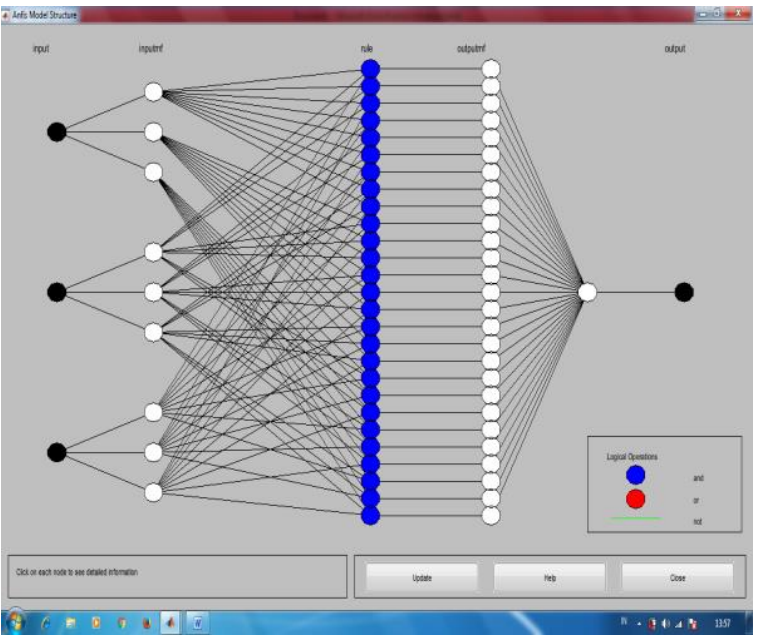

Gbr. 3 Struktur ANFIS

Pada gambar 3, menunjukkan bahwa Anfis menghasilkan 27 aturan, 101 titik plot, jumlah simpul: 78, jumlah parameter linier: 27, jumlah parameter nonlinier: 27, jumlah total parameter: 54, jumlah pasangan data pelatihan: 4, jumlah memeriksa pasangan data: 0, dan jumlah aturan fuzzy: 27. Sehingga, memiliki kesalahan sebesar 0,0189149\%.

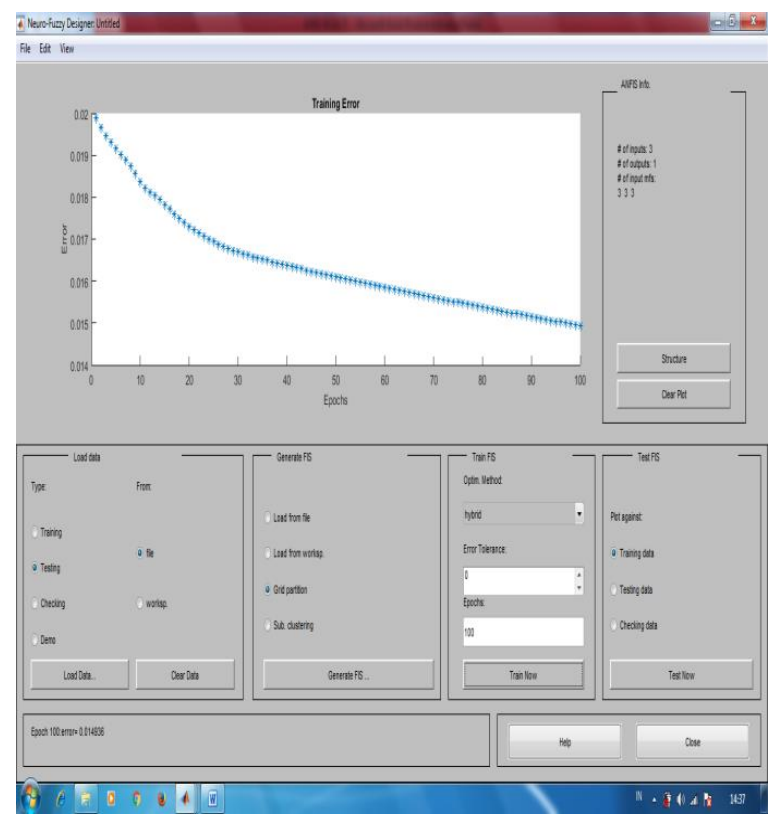

Gbr. 4 Hasil ANFIS

Berdasarkan gambar 4 diatas, bahwasannya perbandingan hasil perkiraan ANFIS memiliki nilai kesalahan yang kecil dengan data aktual. Dan menghasilkan pertumbuhan sebesar 2,07\%. Sehingga hasil perkiraan konsumsi energi listrik di Provinsi Aceh pada tahun 2018-2028 dapat dilihat pada Tabel 1.
TABEL I

HASIL PERKIRAAN KONSUMSI ENERGI LISTRIK DI PROVINSI ACEH TAHUN 2018-2028

\begin{tabular}{|c|c|}
\hline Tahun & $\begin{array}{c}\text { Hasil Perkiraan Konsumsi } \\
\text { Energi Listrik Provinsi Aceh } \\
\text { (GWh) }\end{array}$ \\
\hline 2017 & 2459,24 \\
\hline 2018 & 2510,88 \\
\hline 2019 & 2766,98 \\
\hline 2020 & 3049,21 \\
\hline 2021 & 3360,22 \\
\hline 2022 & 3703,22 \\
\hline 2023 & 4080,94 \\
\hline 2024 & 4496,25 \\
\hline 2025 & 4586,17 \\
\hline 2026 & 4903,95 \\
\hline 2027 & 5304,15 \\
\hline 2028 & 5578,02 \\
\hline
\end{tabular}

Dari Tabel 1 yang disajikan, perkiraan konsumsi listrik di Provinsi Aceh telah dihitung dengan menggunakan Adaptive Neuro Fuzzy Inference System dengan perkiraan pertumbuhan rata-rata $2,07 \%$ per tahun. Kemudian nilai Mean Absolute Percentage Error (MAPE) akan dihitung antara hasil ANFIS dan data aktual atau perkiraan konsumsi listrik dari PT. PLN (Persero) dengan menggunakan persamaan:

MAPE $=\frac{\left(\frac{2459,24-2409,10}{2409,10}\right)}{10} \times 100 \%=0,002 \%(2017)$

Dan dari perhitungan Mean Absolute Percentage Error (MAPE) ini akan dibandingkan hasil dari ANFIS dengan hasil perkiraan konsumsi energi listrik PT. PLN (Persero) Tahun 2017-2032. Dan dapat dilihat pada Gambar 5.

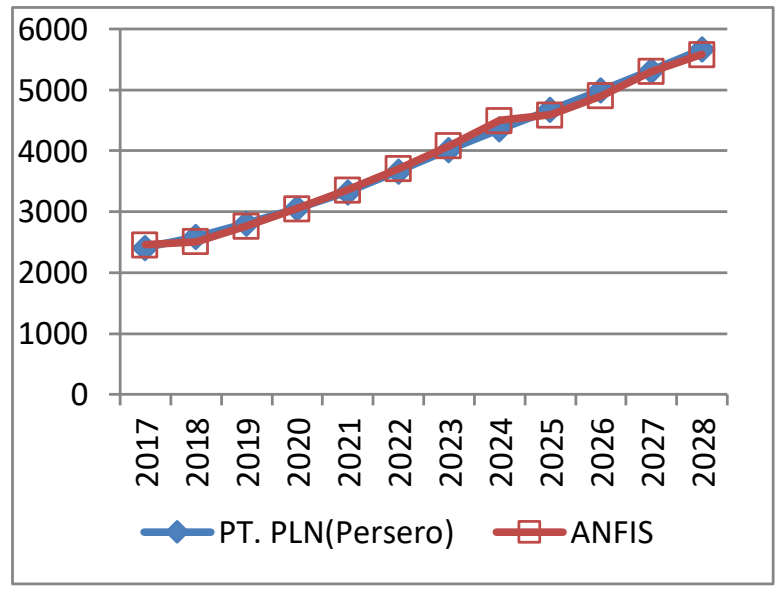

Gbr. 5 Grafik Perbandingan Hasil Perkiraan Konsumsi Energi listrik Aceh Menggunakan Data Dari PT. PLN (Persero) Dengan Perolehan ANFIS. 


\section{PENUTUP}

Berdasarkan hasil yang dilakukan dalam penelitian ini, bahwa dapat diambil kesimpulan yaitu :

1. Faktor-faktor yang mempengaruhi tingkat konsumsi listrik adalah:

Page | 108

a. Pertumbuhan Penduduk

b. Pertumbuhan ekonomi

2. Prakiraan konsumsi listrik di Aceh pada tahun 2028 menggunakan metode Adaptive Neuro Fuzzy Inference System sebesar 5578,02 GWh atau meningkat sekitar $2,07 \%$ setiap tahun hingga tahun 2028.

3. Metode Adaptive Neuro Fuzzy Inference System ini memiliki tingkat kesalahan (MAPE) sebesar $0,002 \%$ dari hasil realisasi atau perkiraan konsumsi listrik di PT. PLN (Persero). Dan metode ini sangat efektif untuk ramalan jangka pendek hingga jangka panjang.

\section{UCAPAN TERIMA KASIH}

Penulis mengucapkan terima kasih kepada kedua orang tua yang telah mendukung dalam penulisan penelitian ini, dan juga kepada pembimbing Bapak Dr. M. Fitra Zambak, M.Sc., dan Bapak Arnawan Hasibuan, S.T., M.T., yang telah memberikan saran, dukungan sehingga dapat menyelesaikan tulisan penelitian ini.

\section{REFERENSI}

[1] A. Hasibuan and W. V. Siregar, "Prakiraan Kebutuhan Energi Listrik Kota Subulussalam Sampai Tahun 2020 Menggunakan Metode Analisis Regresi," $R$ E L E (Rekayasa Elektr. dan Energi) J. Tek. Elektro, vol. 1, pp. 0-4, 2019.

[2] P. Agung, D. Hartono, and A. A. Awirya, "Pengaruh Urbanisasi Terhadap Konsumsi Energi Dan Emisi CO2: Analisis Provinsi di Indonesia," J. Ekon. Kuantitatif Terap., pp. 9-18, 2018.

[3] R. Finata, "Prakiraan Konsumsi Energi Listrik Di Sumatera Utara Pada Tahun 2025 Menggunakan Metode Regresi Dalam Aplikasi Simple E," Tugas Akhir UMSU, 2015.

[4] I. Haimi, "Peramalan Beban Listrik Jangka Pendek Dengan Menggunakan Metode ANFIS," UINSUSKA, 2010.

[5] A. Azadeh, M. Saberi, V. Nadimi, M. Iman, and A. Behrooznia, "An Integrated Intelligent Neuro-Fuzzy Algorithm for LongTerm Electricity Consumption: Cases of Selected EU Countries," Acta Polytech. Hungarica, vol. 7, no. 4, pp. 71-90, 2010.

[6] L. K. Widyapratiwi, I. P. A. Mertasana, and I. G. D. Arjana, "Peramalan Beban Listrik Jangka Pendek Di Bali Menggunakan Pendekatan Adaptive Neuro Fuzzy Inference System," Teknol. Elektro, vol. 11, no. 1, 2012. 